Journal of

Strategic Management

(JSM)

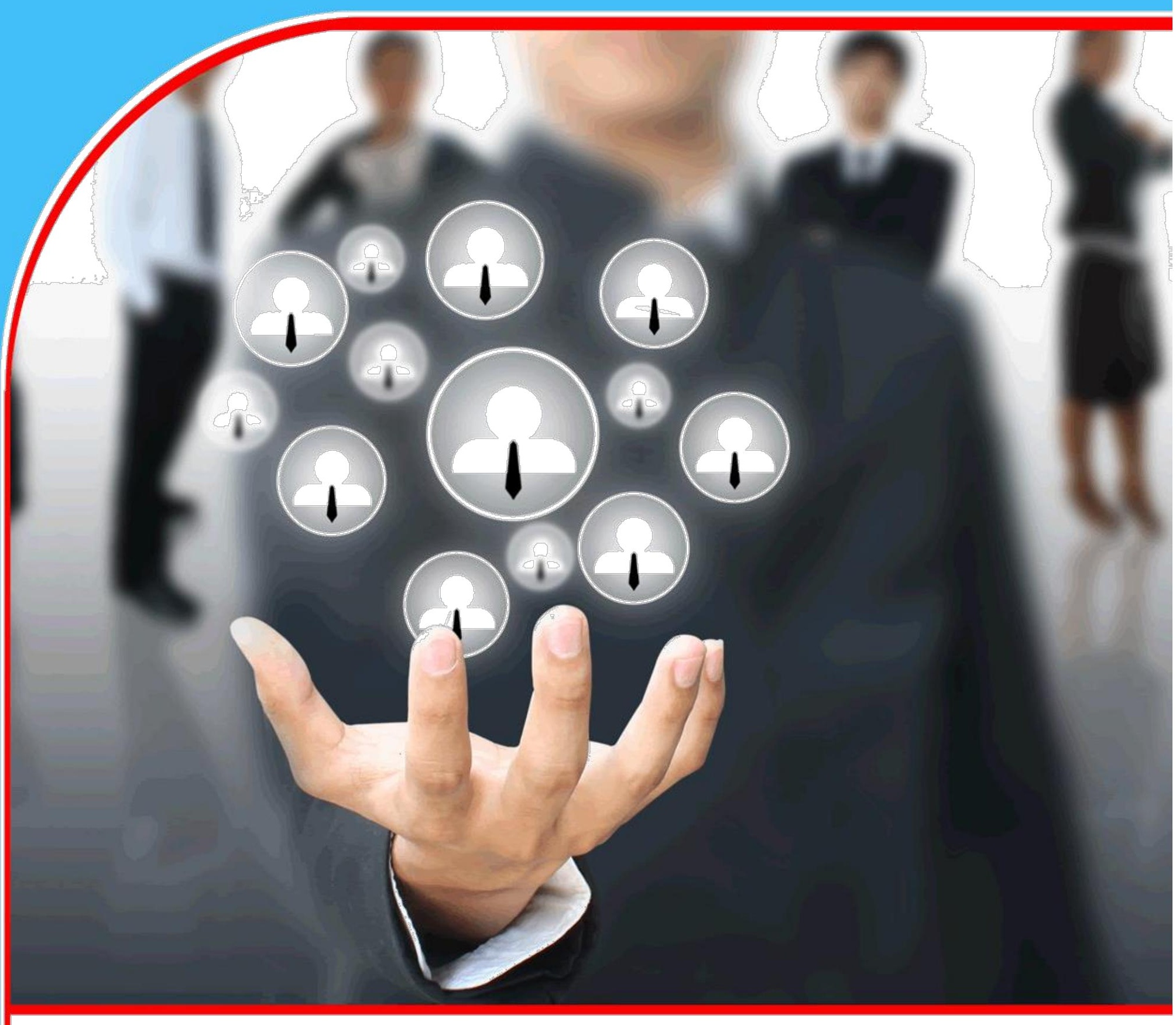

STRUCTURAL CHANGE MANAGEMENTAND EMPLOYEE PERFORMANCE IN PUBLIC SECTOR ORGANIZATIONS IN KENYA: CASE OF THE PARLIAMENTARY SERVICE COMMISSION

Andrew Shangarai Jumanne and Dr. Jane Njoroge (PhD)

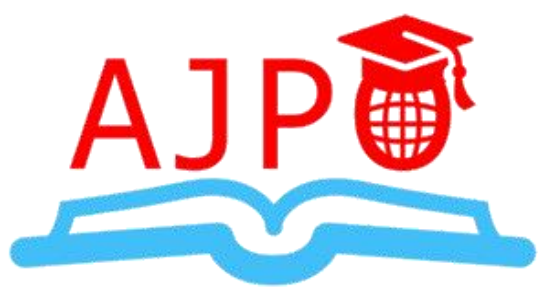




\title{
STRUCTURAL CHANGE MANAGEMENTAND EMPLOYEE PERFORMANCE IN PUBLIC SECTOR ORGANIZATIONS IN KENYA: CASE OF THE PARLIAMENTARY SERVICE COMMISSION
}

\author{
${ }^{1}$ Andrew Shangarai Jumanne \\ Post Graduate Student; Kenyatta University \\ Email address; kakaasjumanne@gmail.com \\ ${ }^{2}$ Dr. Jane Njoroge (PhD) \\ Lecturer, Kenyatta University \\ Email address; strategicgakenia@gmail.com
}

\begin{abstract}
Purpose: The purpose of this study was to analyze the effect of structural change management on employee performance in the Parliamentary Service Commission (PARLSCOM) and it was undertaken through descriptive research design.

Methodology: The study targeted all the nine hundred and fourteen employees of PARLSCOM. Stratified and simple random sampling techniques were used to select a sample of ninety one participants from the target population. Self-administered questionnaire and interview guides were used to collect primary. Secondary data was obtained from PARLSCOM's annual reports, government publications and earlier research. Reliability of the instruments was tested using Cronbach's alpha reliability. Data was analyzed using descriptive and inferential statistics. Multiple linear regression analysis was done using Microsoft Excel 2013 Analysis ToolPak and output used to test study hypotheses.

Results: The results indicated that structural change management had a positive significant effect on performance of employees in PARLSCOM.

Unique contribution to the theory, practice and policy: The study recommends that structural change management is a critical factor in increasing employee performance, therefore HR managers should ensure clarity and stability in the organization's structure during change management in order to enhance employee performance. Finally, the study recommends further research be done by replicating the same study in other organizations and also using other independent variables other than the ones used in this study.
\end{abstract}

Key words: Structural Change Management, and Employees' Performance June 2018 


\subsection{INTRODUCTION}

\subsection{Study background}

Success or failure of an organization depends on performance of its employee. Public organizations often need to implement changes in governance, design and delivery of public services and that, employees play a central role in implementation of these changes (Carter, Armenakis \&Mossholder, 2013; Van der Voet, Kuipers and Groeneveld, 2016). Madan, Jasleen and Bajwa (2016) in their study in India found that employees are the main component of an organization without which accomplishment of objectives is rarely possible.

According to Harper (2015) organizational structure is the hierarchical arrangement of lines of authority, communications, rights and duties of an organization. The structure of an organization determines how the roles, powers, and responsibilities are assigned, controlled and coordinated and how information flows between different levels of management. An organizations structure can be centralized or decentralized. In a centralized structure, decision making is a preserve of the top management who also have tight control over departments and divisions.

Organizations may find it necessary to change their organization structures in order to remain competitive or adapt to changes that have happened or are anticipated to happen to the organization. Organizational structure defines the way employee's complete tasks and interact with each other in the organization. Organizational structural changes can inhibit or promote employee performance, depending on how effectively the supervisory relationships and workflow influences productivity (Amed, Rehman, Asad \& Bilal, 2013).

According to Lewin's Three-Step Change Theory, there are three steps through which organizational change should go through. These include; unfreezing, change and refreezing. Under unfreezing, employees are made aware of the current state of things in the organization and the need to change them. The second stage is to implement the change thought of in the unfreezing state. The third stage in refreezing, during refreezing, the implement change is guarded to ensure it is fully adopted by the employees and that there is no room for people to return to the previous ways of doing things (Cummings, Bridgman \& Brown, 2016).

\subsubsection{Parliamentary Service Commission}

The Parliamentary Service Commission (PSC) was established through an Act of Parliament in the year 2000. The mandate of the Commission is to facilitate the members of parliament to efficiently and effectively perform their roles of legislation, oversight, budget making and representation of the people of Kenya (PARLSCOM; Republic of Kenya, 2010). The new constitutional dispensation had far reaching implications on the leadership, structure, roles and functions of Parliament. This entailed availing all the infrastructure including, offices and other amenities required for the two Houses of Parliament in time for the new Parliament (Constitution of Kenya, 2010). The study investigated the effect of management of these changes on performance of employees.

\subsection{Problem Statement}

Public sector reforms have been advocated by scholars as a necessary remedy for poor employee performance for many developing countries. The new constitution adopted in Kenya in 2010 had far reaching changes in the parliamentary service commission's structure, (PARLSCOM; Republic of Kenya, 2010). This study sought to examine the effect of structural change management on employee performance. 


\subsection{Research Objectives}

i. To establish whether structural change affect employee performance of the Parliamentary Service Commission of Kenya

\subsection{Study Hypotheses}

Based on the research objectives, the following null-hypothesis were formulated tested on five percent level of significance $(\alpha=0.05)$

$\mathbf{H}_{01}$ : There is no relationship between structural change management and employee

Performance

\subsection{Scope of the Study}

This study focused on organizational change management and employee performance in the public sector organizations using the case of the Parliamentary Service Commission of Kenya. The study sought to examine the relationship between organizational change management and employee performance in the Parliamentary Service Commission in Kenya.

\subsection{REVIEW OF RELATED LITERATURE}

\subsection{Empirical Literature Review}

\subsubsection{Employee Performance}

Ochoti, Maronga, Muathe, Nyabwanga and Ronoh (2012) investigated factors influencing Employee Performance Appraisal System in the Ministry of State for interior and coordination, Nyamira county Kenya. The study used multiple regression analysis technique to explain the nature of the relationship between Employee Performance Appraisal System (PAS) (dependent variable) and the factors that influence it, (independent variables) which included implementation process, interpersonal relationship, ratter accuracy, Informational factors and employee attitudes. The results of the study showed that $55.1 \%$ of the variation in performance of employees can be explained by the changes in implementation process, interpersonal relationships, ratter accuracy, informational factors and employee attitudes. The study recommended further research to be conducted to determine the influence of the PAS outcome on employee performance.

An empirical study carried out by Uzonna (2013) to identify the impact of monetary and nonmonetary motivation on employee performance found that the use of non-cash rewards is more effective and cost-efficient way to boost employee performance. The non-monetary motivation variables discussed included: Recognition, challenging work, advancement and opportunities, job autonomy, authority, job security, prestigious job titles and responsibility. The monetary motivation variables discussed include; fringe benefits, salary, bonuses, pensions, profit sharing and performance pay. The study further found that when it comes to bringing out the best performance of employees, growth opportunities and challenges, recognition and non-cash rewards are more effective motivators than money.

The study used monetary and non-monetary motivation as the independent variables while the current study technological change management, structural change management, cultural change management and leadership change management as the independent variables. The 
dependent variable which is employee performance was the same for both studies. Change management affects employees' performance in various dimensions (Wanza \& Nkuraru, 2016). The study was investigated the influence of change management on employee performance at University of Eldoret, Kenya; similar to this in the Public Sector Organizations in Kenya with regard to the Parliamentary Service Commission.

\subsubsection{Structural Change Management and Employee Performance}

According to Harper (2015), Structural changes are those changes made to the organization's structure that might stem from internal or external factors and typically affect how the company is run. Structural changes include things such as the organization's hierarchy, chain of command, management systems, job structure and administrative procedures. Circumstances that usually create the need for structural change management include mergers and acquisitions, job duplication, changes in the market and process or policy changes. Scott (2015) pointed out that Structural change management within organizations is inevitable. The emergency of new roles and responsibilities into new positions requires changes in the current organizational structure to enable the organization to respond and adapt to the changing demands from both internal and external environments.

Duplessis and Vanniekerk (2014) further specified that organizational structure comprise of positions, work units, liaison groups, hierarchical layers, communication channels, and reward systems that enable or limit organizations' ability to adapt and respond to the changing environment in which they exist. Foss, Laursen and Pedersen (2011) argued that firms that attempt to leverage user and customer knowledge in the context of innovation must design internal organizational structures that are appropriate to support it. This can be achieved through the use of new organizational practices, notably, intensive vertical and lateral communication, rewarding employees for sharing and acquiring knowledge, and high levels of delegation of decision rights.

Maina (2013) in a study to determine the strategic change management practices adopted by savings and credit cooperative societies in the public sector in Kenya found that structural changes, technological changes, organizational leadership practices, changes in political and economic environment to be the main factors that contributed to change in the savings and credit cooperative societies. The study further found that the SACCOs in the public sector had adopted structural change, in their activities and hence were not benefiting with benefits that comes with it. The study recommended that the savings and credit cooperative societies should embrace restructuring and corporate governance practices in all sectors of the organization to improve on their service delivery and profitability.

The study sought to determine the strategic change management practices adopted by savings and credit cooperative societies in public sector within the Kenyan context. The design of this research was cross sectional research design. The current study sought to analyse the effects of organizational change management on employees' performance in the Parliamentary Service Commission in Kenya. It was carried out using descriptive research design.

Kimathi (2016) in a study that investigated the influence of strategic change management practices at Coca Cola Company in Kenya, revealed that incompatibility of the new change with existing organization structure, information technological innovations, political interference, social factors and consumer behaviour among key challenges faced by the 
company. The study used three step theory of change, force field analysis theory and Kanter model of change management and was conducted through a case study.

\subsection{Theoretical Review}

\subsubsection{Lewin's Three-Step Change Theory}

Lewin (1951) introduced the three-step change theory. Lewin viewed behaviour as a dynamic balance of forces working in opposing directions. Driving forces facilitate change because they push employees in the desired direction. Restraining forces hinder change because they push employees in the opposite direction.

According to Lewin, the first step in the process of changing behaviour is to unfreeze the existing situation or status quo. During the unfreezing stage awareness of how the status quo is hindering the organization in some way is created. Communication is important during the unfreezing stage so that employees can become informed about the imminent change, the logic behind it and how it benefits each employee. The idea is that the more the employees know about a change and the more they feel it is necessary and urgent, the more motivated they are to accept it (Brisson-Banks, 2010). This changing is marked by the implementation of the change; the change becomes real. During the changing step people begin to learn the new behaviours, processes and ways of thinking. During this step, education, communication, support and time are critical for employees as they become familiar with the change (Hamel \& Prahalad, 2013)

The final stage of Lewin's three-step change model is the stage of reinforcing, stabilizing and solidifying the new state after the change. The technological, cultural, structural changes made are accepted and refrozen as the new norm or status quo. Lewin found the refreezing step to be especially important to ensure that people do not revert back to their old ways of thinking or doing prior to the implementation of the change (Wambua, 2012; Vincent, 2013; Coghlan, Rashford \& Figueiredo, 2015). Efforts must be made to guarantee the change is not lost; rather, it needs to be cemented into organization's culture and maintained as the acceptable way of thinking or doing.

\section{ORESEARCH METHODOLOGY}

\subsection{Research Design}

The study was carried out through a descriptive research design. According to Garg and Kothari (2014) the purpose of descriptive research design, is to collect detailed and factual information that describes an existing phenomenon. It attempts to describe such things as possible behavior, attitudes, values and characteristics as they exist. Explanatory research design was also be used in giving clarifications as to why and how the variables are interdependent and also explain the relationship between the variables and the results of the research.

\subsubsection{Empirical Model}

The model was presented in a linear equation form as shown below.

$E_{P}=\beta_{0}+\beta_{1} S c+\varepsilon$

Where, 
$\mathrm{EP}=$ Employee Performance

$\beta_{0}=$ Constant

$\beta_{1=}$ Slope

$\mathrm{Sc}=$ Structural Change Management

$\varepsilon=$ Error Term

\subsection{Target Population of the Study}

The study was conducted at the Parliamentary service commission offices in Nairobi Kenya. The target population of study was all the 914 permanent and pensionable employees of Parliamentary service commission (PARLSCOM; Republic of Kenya, 2010

\subsection{Sampling Method}

Stratified sampling was used because it was possible to sub-divide the target population into three mutually exclusive strata that were based on the sector of service. The three sectors included the National Assembly, the Senate and the Joint Service.

\subsection{Sampling technique}

Simple random sampling was the technique used in doing the study and all employees had equal chances of being included into the sampling.

\subsection{Sample Size}

A total of ninety one respondents were identified and questionnaires were administered to them. This is in consistent with Mugenda (2003), that $10 \%$ of the accessible population is enough for a sample size that is a representative of the study population. The sample size was therefore 91 permanent and pensionable employees of Parliamentary service commission

\subsection{Data collection procedure}

The researcher developed a questionnaire that addressed employee performance and issues of structural change management which included leadership change management, structural change management, technological change management and cultural change management. The questionnaire contained questions which sought the respondents view on structural change management and employee performance. The questionnaire was pre-tested using the first four respondents who did not form part of the study sample. Thereafter, the tool was refined and data collection commenced. The researcher also conducted face-to-face interviews with one interviewee from each sector of service i.e. the national assembly, the senate and the joint service.

\subsection{Data analysis}

Data was analyzed using descriptive and inferential statistics. Descriptive statistics such as percentages was used to summarize data while inferential statistics, specifically multiple linear regression was used to test hypotheses. The regression analysis was done using Microsoft Excel 2013 Analysis ToolPak. 


\subsection{DATA PRESENTATION, ANALYSIS AND DISCUSSION}

\subsection{Profile of the Respondents}

The respondents were categorized into three categories: National Assembly, the Senate and the Parliamentary Joint Service

Table 4. 1 Category of Respondents

\begin{tabular}{lcccc}
\hline Parliamentary Service & Male & Female & Total & Percentage \\
\hline National Assembly & 10 & 6 & $\mathbf{1 6}$ & $\mathbf{2 1}$ \\
Senate & 4 & 4 & $\mathbf{8}$ & $\mathbf{1 1}$ \\
Parliamentary Joint Service & 29 & 23 & $\mathbf{5 2}$ & $\mathbf{6 8}$ \\
Total & $\mathbf{4 3}$ & $\mathbf{3 3}$ & $\mathbf{7 6}$ & $\mathbf{1 0 0}$ \\
Percentage & $\mathbf{5 7}$ & $\mathbf{4 3}$ & $\mathbf{1 0 0}$ & \\
\hline
\end{tabular}

Source: (Researcher, 2017)

From the results above, majority (68\%) of the respondents were from the Parliamentary Joint Service. The results also showed that no gender had more than two thirds of the respondents.

\subsection{Regression Analysis}

Regression Analysis was used to test the entire hypothesis. Regression results are shown in

Table 4. 2 Regression results for Structural change management factors and Employee Performance

SUMMARY OUTPUT

\begin{tabular}{ll}
\hline Regression Statistics & \\
\hline & 0.8359924 \\
Multiple R & 27 \\
& 0.6988833 \\
R Square & 38 \\
& 0.6819190 \\
Adjusted R Square & 19 \\
& 0.3635364 \\
Standard Error & 38 \\
Observations & 76 \\
\hline
\end{tabular}




\begin{tabular}{|c|c|c|c|c|c|c|c|}
\hline & $\begin{array}{l}\text { Coefficien } \\
\text { ts }\end{array}$ & $t$ Stat & $P$-value & $\begin{array}{l}\text { Lower } \\
95 \%\end{array}$ & $\begin{array}{l}\text { Upper } \\
95 \%\end{array}$ & $\begin{array}{l}\text { Lower } \\
95.0 \%\end{array}$ & $\begin{array}{l}\text { Upper } \\
95.0 \%\end{array}$ \\
\hline Intercept & 0.452712 & $\begin{array}{l}1.700 \\
01\end{array}$ & $\begin{array}{l}0.0935 \\
05\end{array}$ & -0.0782 & 0.98369 & -0.07827 & 0.983698 \\
\hline $\begin{array}{l}\text { Structural Change } \\
\text { Management }\end{array}$ & 0.271871 & $\begin{array}{l}3.617 \\
08\end{array}$ & $\begin{array}{l}0.0005 \\
53\end{array}$ & 0.1220 & 0.42174 & 0.122000 & 0.421742 \\
\hline
\end{tabular}

Source: (Researcher, 2018)

Table 4.2 shows that the adjusted R-squared is $68.2 \%$ meaning that the independent variables explain 68.2 percent of variations in the dependent variable, while the remaining $31.8 \%$ of the variations in Employees' Performance is explained by other variables not included in the model. Structural Change Management coefficient is positive and significant at 0.272 and $\mathrm{P}$ value $=0.001<0.05$ a unit increase in Structural Change Management would lead to an increase in employee performance by 0.272 units

\subsection{Testing of Hypotheses}

\section{$H_{01}$ There is no relationship between structural change management and employee Performance}

To determine whether structural change management affects the performance of employees of Parliamentary Service Commission in Kenya, null hypothesis $\mathbf{H}_{\mathbf{0 1}}$ was formulated, with the assumption that there is no relationship between structural change management and employee Performance in Parliamentary Service Commission in Kenya. Table 4.9 shows that the coefficient of structural change management was 0.27 , the t-statistic and corresponding pvalue were 3.62 and $0.001<0.05$ respectively. Therefore, at five percent level of significance, the null hypothesis is rejected, implying that structural change management has a significant effect on the performance of employees of Parliamentary Service Commission in Kenya.

Since the coefficient for structural change management is positive and significant, it can be inferred that structural change management has a positive effect on performance of employees of Parliamentary Service Commission in Kenya. This is in line with Foss, Laursen and Pedersen (2011) findings that firms seeking to leverage user and customer knowledge designed internal organizational structures appropriate through the use of new organizational practices, notably, intensive vertical and lateral communication, rewarding employees for sharing and acquiring knowledge, and high levels of delegation of decision rights. It was also found that Structural change management enabled the organization to respond and adapt to the changing demands from both internal and external environments thus improving employees' performance. 


\subsection{CONCLUSIONS AND RECOMMENDATIONS}

\subsection{Conclusion}

Organizations need highly performing employees to accomplish their goals; to deliver the products and services they specialize in. Improved employee performance implies better delivery of public services to both government and the citizenry. This has the potential to improve livelihoods, and sustain good governance (Hope, 2012). In this study, the researcher examined how structural change management affected performance of employees in the parliamentary service commission in Kenya, and concludes that Structural Change Management had a statistical significant effect on the performance of employees of the parliamentary service commission of Kenya. It therefore implies that organizations should clearly define the Roles and responsibilities of each employee and consider merging similar roles and departments to avoid duplication of duties if they want to improve efficiency in employee performance.

\subsection{Contributions of the Study to Knowledge}

The study focused on structural change management and employee performance, particularly in the parliamentary service commission. This would be beneficial to the management in understanding key change management factors that influence performance of employees. The empirical data herein may provide evidence in formulating strategies, policies, and building effective and efficient processes for organizational change management. The findings from this study also are beneficial to researchers and other human resource managers by providing the scholarly literature on structural change management and employee performance in the public sector organizations.

\subsection{Recommendations for Policy Implication}

These findings confirm the study's conceptual model and recommend that human resource managers place employees at the central point when managing organizational change. Human resource managers need to put more effort by investing in people through training and development to enhance knowledge and skills. They should also ensure that their employees participate in setting organizational values, rules and regulations. Management should pay more attention to technological changes and encourage use of ICT automations while managing change. In addition, the management should put more emphasis and pay additional attention to innovations since they were found to leads to high employee performance.

\subsection{Recommendation for Further Research}

The researcher recommends that a similar research should be conducted in other public organizations in Kenya. The current research can be duplicated in order to compare and validate the findings of this study. Further studies should also be carried out to investigate change management factors affecting employee performance in the public sector. 


\section{REFERENCES}

Ahmed, Z., Rehman, Z. U., Asad, A., Hussain, N., \& Bilal, A. (2013). The impact of organizational change on the employee's performance in banking sector of Pakistan. Ethiopian International Journal of Multidisciplinary Research, 1(1), 1-12.

Brisson-Banks, C. V. (2010). Managing change and transitions: a comparison of different models and their commonalities. Library Management, 31(4/5), 241- 252.

Carter, M. Z., Armenakis, A. A., Feild, H. S., \& Mossholder, K. W. (2013). Transformational leadership, relationship quality, and employee performance during continuous incremental organizational change. Journal of Organizational Behavior, 34(7),942958.

Coghlan, D., Rashford, N. S., \& de Figueiredo, J. N. (2015). Organizational change and strategy: An interlevel dynamics approach. Routledge.

Constitution of Kenya. (2010). Government Printer- Nairobi, Kenya.

Cummings, S., Bridgman, T., \& Brown, K. G. (2016). Unfreezing change as three steps: Rethinking Kurt Lewin's legacy for change management. Human relations, 69(1), 3360.

Cummings, T. G., \& Worley, C. G. (2014). Organization development and change. Cengage learning.

Du Plessis, H., \& Van Niekerk, A. (2014). A new GISc framework and competency set for curricula development at South African universities. South African Journal of Geomatics, 3(1), 1-12.

Foss, N. J., Laursen, K., \& Pedersen, T. (2011). Linking customer interaction and innovation: The mediating role of new organizational practices. Organization Science, 22(4), 980999.

Frank, S. A. (2011). What Does It Take To Motivate Better Performance and Productivity in the Federal Workplace? Ask the Employees.

Garg, G., \& Kothari, C. R. (2014). Research Methodology. Methods and Techniques. New Age International Publishers. New Delhi-110002.

Hamel, G., \& Prahalad, C. K. (2013). Competing for the Future. Harvard Business Press.

Harper, C. (2015). Organizations: Structures, processes and outcomes. Routledge.

Hope, K. R. (2013). Managing the public sector in Kenya: reform and transformation for improved performance. Journal of Public Administration and Governance, 2(4), 128143.

Kimathi, F. M. (2016). Factors Influencing Strategic Change Management Practices At Coca Cola Company In Kenya (Doctoral dissertation, University of Nairobi). 
Madan, D. P., \& Bajwa, J. K. (2016). Human Resource Management Practices and their Impact on the Job Performance of Employees with Special Reference to Banking Sector. International Journal of Engineering Technology, Management and Applied Sciences, 4(4).

Maina, P. K. (2013). Strategic Change Management Practices Adopted By Saving And Credit Co-operative Societies In Public Sector In Kenya (Doctoral dissertation, University of Nairobi).

Mugenda, O. \& Mugenda, A. (2003). Research methods, quantitative and qualitative approaches, Nairobi Acts press.

Ochoti, G. N., Maronga, E., Muathe, S., Nyabwanga, R. N., \& Ronoh, P. K. (2012). Factors influencing employee performance appraisal system: a case of the ministry of state for provincial administration \& internal security, Kenya. International Journal of Business and Social Science, 3(20).

PARLSCOM; Republic of Kenya (2010). Parliamentary Service Commission Annual

PARLSCOM; Republic of Kenya (2010). Parliamentary Service Commission Report of the Report.

Scott, W. R. (2015). Organizations and organizing: Rational, natural and open systems perspectives. Routledge.

Task force on Implementation of the New Constitution.

Uzonna, U. R. (2013). Impact of motivation on employees' performance: A case study of Credit West Bank Cyprus. Journal of Economics and International Finance, 5(5), 199.

Van der Voet, J., Kuipers, B. S., \& Groeneveld, S. (2016). Implementing Change in Public Organizations: The relationship between leadership and affective commitment to change in a public sector context. Public Management Review, 18(6), 842-865.

Wambua, S. M. (2012). Management of strategic change at Nairobi Automated Clearing House (Doctoral dissertation, University of Nairobi, Kenya).

Wanza, S. L., \& Nkuraru, J. K. (April 2016) Influence of Change Management on Employee Performance: A Case of University of Eldoret, Kenya. International Journal of Business and Social Science Vol. 7, No. 4 